\title{
Pressupostos para a formação do mediador de conflitos na Teologia Pastoral, tendo como instrumental materiais áudio visuais
}

Orientador: Prof. Abimar Oliveira de Moraes

Pesquisador: Edmilton Neves Romão

Fonte: $\mathrm{CNPq}$

\section{Introdução}

Vivemos em um tempo que outrora preza demasiadamente a imagem, o som, enfim a interatividade. Com essa abertura épocal podemos usufruir dos mecanismos que as tecnologias nos apresentam. Aqui elencamos os pequenos vídeos de animação, nos quais buscam apresentam ao mediador de conflitos e as pessoas envolvidas nos conflitos, instrumentais que facilitam a busca do bem-estar para ambas as partes.

Percebemos que chega a um dado momento que as palavras, não conseguem alcançar a sua eficácia no ambiente de mediação, daí recorrermos aos pequenos vídeos, como pressupostos para a mediação de conflitos. Compreendendo os seus limites, no que tange a intencionalidade de quem produz o vídeo e que o usa para a mediação. Tendo presente a interpretação do mesmo; vislumbrando as comunidades interpretativas como ambientação eficaz para que se aconteça à mediação.

O papel da formação do mediador de conflitos, onde o mesmo tem a possibilidade de relacionar com as mídias, buscando na mesma as potencialidades que ela pode apresentar no exercício de mediações de conflitos. Ambos os pressupostos são processos pedagógicos para uma busca cada vez mais arraigada de fazer surgir linguagem, que inclua as pessoas em seus complexos conflitos, para isto o mediador precisa ser "bem formado", ou seja, aberto ao universo das relações e conflitos que a sociedade o apresentar. 


\section{Objetivos}

Essa pesquisa propõe-se a refletir sobre a prática da Mediação de conflitos no âmbito da formação do mediador de conflitos. Propondo ao mesmo o uso de materiais audiovisuais, como composição de sua formação enquanto mediador e a importância dessas mídias para os processos pedagógicos na mediação de conflitos. 